\title{
Basic Locomotor Motion Characteristic Design Using Games Model for Elementary School Student
}

\author{
Hary Muhardi Syaflin ${ }^{1, *}$, Fatah Nurdin ${ }^{1}$, Widiastuti ${ }^{1}$, Syafaruddin $^{2}$, \\ Muhsana El Cintami Lanos ${ }^{3}$, Sylvia Lara Syaflin ${ }^{3}$ \\ ${ }^{1}$ Sport Education, Program Pasca Sarjana, Universitas Negeri Jakarta, Indonesia \\ ${ }^{2}$ Sport Education, Universitas Negeri Sriwijaya, Indonesia \\ ${ }^{3}$ Sport Education, Universitas PGRI Palembang, Indonesia
}

Received February 19, 2021; Revised April 14, 2021; Accepted May 11, 2021

\section{Cite This Paper in the following Citation Styles}

(a): [1] Hary Muhardi Syaflin, Fatah Nurdin, Widiastuti, Syafaruddin, Muhsana El Cintami Lanos, Sylvia Lara Syaflin, "Basic Locomotor Motion Characteristic Design Using Games Model for Elementary School Student," International Journal of Human Movement and Sports Sciences, Vol. 9, No. 3, pp. 560 - 567, 2021. DOI: 10.13189/saj.2021.090323.

(b): Hary Muhardi Syaflin, Fatah Nurdin, Widiastuti, Syafaruddin, Muhsana El Cintami Lanos, Sylvia Lara Syaflin (2021). Basic Locomotor Motion Characteristic Design Using Games Model for Elementary School Student. International Journal of Human Movement and Sports Sciences, 9(3), 560 - 567. DOI: 10.13189/saj.2021.090323.

Copyright $(\mathrm{C} 2021$ by authors, all rights reserved. Authors agree that this article remains permanently open access under the terms of the Creative Commons Attribution License 4.0 International License

\begin{abstract}
Locomotor is a fundamental aspect of learning to move effectively and efficiently. For children, locomotor motion becomes a variety of movement activities in daily activities so that this movement becomes a fun learning process if done through activities. The study aimed to get the concept of basic locomotor motion characteristic using games. Locomotor motion learning increases the students' endurance and academic achievement. The method used to research and development is Dick and Carey procedure. Data are collected using observation, interview, questionnaire, and test. The data analysis used judgment expert and the result of the test using the independent sample t-test. The findings show that students need some variation of basic locomotor motion using traditional games. The motion is walking, running, and jumping which creates 14 basic locomotor motions. They have differences in goals and objectives motion. This model is feasible and effective, which can be used in the school. Also, it can use for the public elementary school in Indonesia because all motion with the traditional games is familiar games for Indonesia children. It is easy to do at school. In Indonesia, many traditional games are used to support learning process in physical activity. Thus, the learning activity can do in the class or out of class.
\end{abstract}

Keywords Elementary School, Locomotor, Physical Motion, Games

\section{Introduction}

Physical Education is a phase of the overall education program that contributes, especially through the experience of movement, growth and development as a whole to each primary school student [1]. Movement, as a basic form of physical activity, meets the needs of students' physical development [2]. Therefore, physical education programs in elementary schools emphasize mastery of movement skills before learning outcomes of physical activities are achieved.

The results of a preliminary study through interviews with five sports teachers in elementary schools in Ogan Ilir Regency, it is known that most of the teachers are trying to create a learning environment which can encourage the development of student potential, but the level of utilization of opportunities for learning resources has not been maximized. This is also reinforced by the results of observations made by researchers in the sport learning process that: (1) the teaching materials are used by teachers for movement skills are still very minimal; (2) face-to-face learning is not appropriate when it compared with the material to be taught to students so that the teacher teaches the material briefly.

The problems found in the preliminary research are influenced by many factors from the students themselves, 
teachers or learning sources. Even though, the physical education program is one of the media in improving students' basic motor skills. Some of the basic motor skills are running, jumping, catching, or throwing [3]. It influenced the sensorimotor scheme [4]. Students will have difficulty completing physical education if their basic motor skills are weak. Students who have competency in fundamental motor skills are successful in participating in various sports. Also, fundamental motor skills competencies help students lead a healthy lifestyle (Gouveia et al., 2020; Williams et al., 2008).

However, the results of the needs analysis for learning movement skills was that the motion material was not varied and monotonous. Thus, many students have problems with basic coordination, balance, left and right orientation, rhythm, and spatial and body awareness. It is necessary to have the characteristics of locomotor skills through various types of games, because children in elementary schools tend to have more fun learning through various forms of games.

Many previous studies have examined the diversity or learning of basic locomotor movement skills. For elementary students, throwing-catching skills affect the level of locomotor ability [7]. Other studies have concluded that various physical activities such as aerobic fitness and basic motor skills influence children's academic achievement (de Bruijn et al., 2019; Grissmer, Grimm, Aiyer, Murrah, \& Steele, 2010; Logan, Kipling Webster, Getchell, Pfeiffer, \& Robinson, 2015). Different research shows that basic movement skills competencies and moderate-to-vigorous physical activity are opportunities in locomotor movement skills (Cohen, Morgan, Plotnikoff, Callister, \& Lubans, 2014; Han, Fu, Cobley, \& Sanders, 2018; Webster, Martin, \& Staiano, 2019). It is concluded that basic movement skills are significantly associated with physical activity habits. Although research Fisher et al. (2005) shows that the relationship between the two is weak.

Currently, this research is urgent to do because of the lack of variations in basic locomotor exercises in elementary schools in Ogan Ilir Regency. Besides, the need for a learning process aimed at developing practical and empirical skills is a demand from the primary school curriculum. Graduates must have a level of academic achievement capable of facing the challenges of the global era, as has been described in previous studies that locomotor movement skills can improve academic achievement. The age between 5 and 12 is a critical period for children to develop fundamental movement skills (FMS). Children who do not master FMS are more likely to experience failure in the motor domain and are less likely to participate in sports and games during childhood and adolescence (Hardy, King, Farrell, Macniven, \& Howlett, 2010; Bryant, Duncan, \& Birch, 2014; Shams, Hardy, Vameghi, Loovis, \& Shamsipour Dehkordi, 2021). Also, FMS is the basis of the early motor marker, especially for autism spectrum disorder [18]

However, this study is different from previous research, because the basic locomotor motion design is made with varied game characteristics according to the age development needs of elementary school students. As traditional games influenced the motoric skills development for the children 7-9 aged ( $\mathrm{H}$ et al., 2009; N \& H, 2017; Hernawan, Sukarya, \& Solahuddin, 2019), it is a gap of study. So, teachers must use the right strategies in the development of motor skills for children [22].

Thus, the purpose of this study is to get the design of basic locomotor motion design with the varied characteristic using games. It is used for the sport learning elementary students. Therefore, this study can make a contribution to the material locomotor skills in sports subject for the children. It is being used as a new reference in district Ogan Ilir for the learning process. Besides, it is a process to increase students' academic achievement. The teacher can design the learning using games in the class to explore students' potency.

\section{Materials and Methods}

\subsection{Research Approach}

The method is research and development method (R\&D). $R \& D$ in education is the development of industry-based models as a result of research findings used to design new products and procedures, then systematically tested in the field, evaluated and selected until they get specific criteria which are effective, quality, or the same standard [23]. Thus, the study creates a new product of basic locomotor motion characteristic using types of games for elementary students.

\subsection{Participants}

This research was conducted in elementary schools in Ogan Ilir Regency, South Sumatera. The research was carried out from July 2019 to May 2020. Participants involved in the product field test were 15 schools in Ogan Ilir Regency with 100 students who were selected randomly from 15 district. 1 school that has the same locomotor motion learning goals is taken from each district. Also, the school has a special program for the locomotor motion which has to full curriculum design. The participant is used to small group trials around 30 students and 100 students for large group trial. Participants' age were 10-11 years and they were in grade 5. Field tests are done in classes that have physical education and sports learning schedule at a predetermined time according to the school schedule. The participant is taken randomly in each school but they receive the locomotor skills material

\subsection{Process of Collecting Data}

Data were collected through several techniques, namely 1) interviews. It is used to analyze students' perception of the practicality of using a game-based locomotor motion learning model. Students who have been involved in product trials in small and large groups, at the end of the lesson were 
interviewed by researchers who were randomized or $70 \%$ of the participants involved in the experimental activities. The interview process is carried out directly by asking about the effectiveness of the locomotor motion model that has been taught and the results of the interview are recorded so that they can become product improvement data. 2) Questionnaire is used to get the needs analysis of basic locomotor motion model from the students and teacher. 100 questionnaires were distributed to students in grade 5 and 30 teachers. The questionnaire is designed using a closed questionnaire type and participants must choose the answers that have been provided related to the questions. Questions are made according to the aspects of basic locomotor motion instruments focused on variations in motor skills knowledge, motor skills learning media, and children's play concepts. The questionnaire consists of five answer choices using a Likert scale. The validity of the instrument used the judgment expert consisting of learning media experts, curriculum experts, and experts in learning locomotor motion or physical activity and sports. While the reliability of questionnaire items used Cronbach's Alpha value. It is $>0.70$, the result of test $0.82>0.70$ and the questionnaire is reliable. 3) Observation is used to know the effectiveness of the trial of the product in the field. 4) The test is used to get the improvement of students' achievement in locomotor skills learning before and after using the new model. There are two types of tests that are given, namely theory and practice. The theory test is given in the form of multiple-choice questions related to the knowledge of students' locomotor motion, while practical test is used to test students' locomotor motion abilities according to the theoretical concepts that have been learned.

\subsection{Procedure}

The procedure of study used ADDIE model [24]. The following is the steps of research:

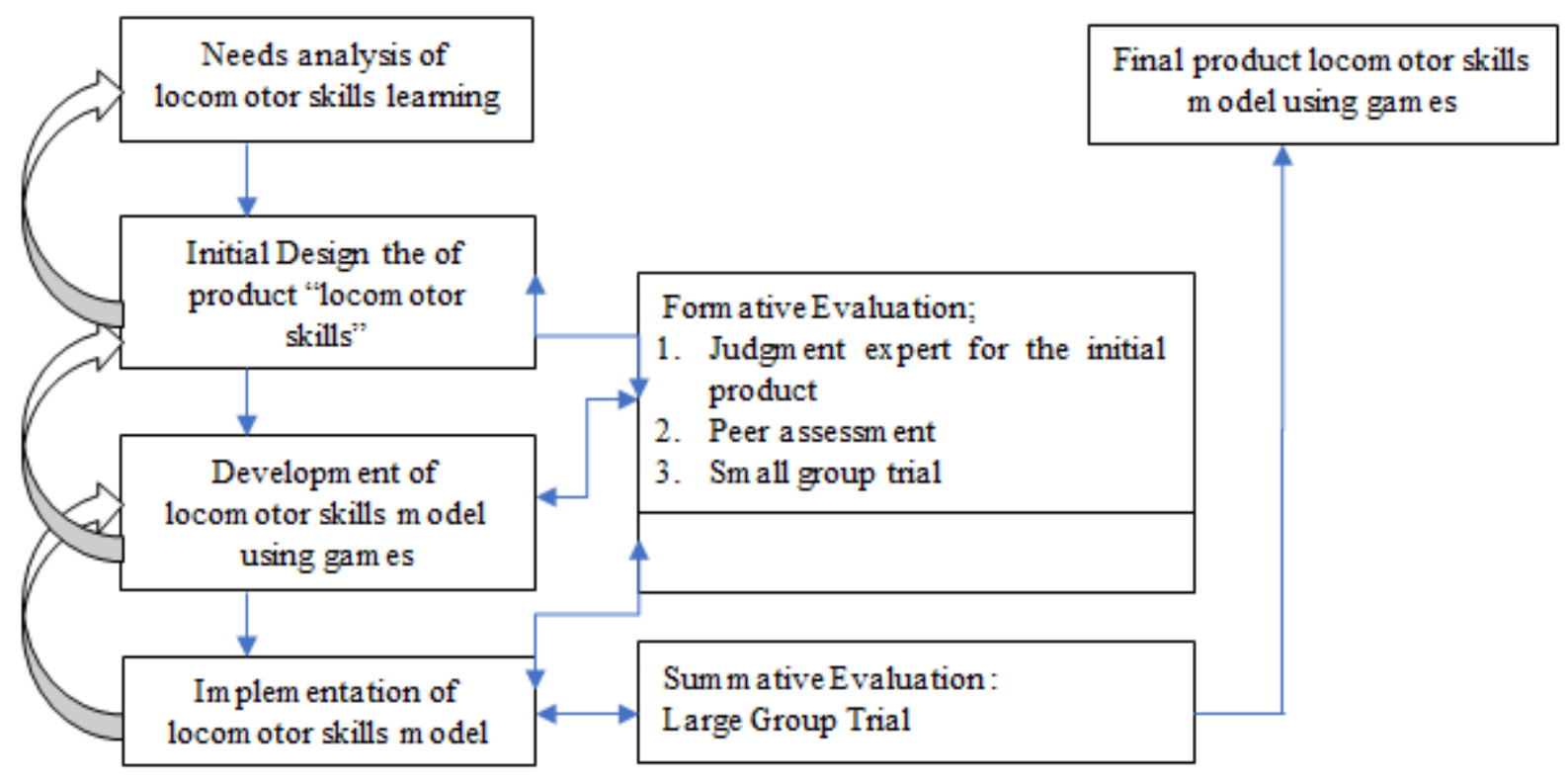

Picture 1. The procedure of research adapted from ADDIE Model 
In the first stage, a needs analysis is carried out on basic locomotor motion skills for elementary school students in learning sports. Needs analysis is used to obtain information about the material needs of students from the basic locomotor motion obtained through interviews and questionnaires. The data obtained through a questionnaire is made in the form of a percentage. At this stage, researchers also conduct literature reviews and data analysis to design products.

In the second stage, the basic locomotor motion skills product is designed, which is followed by an assessment process from experts and peer assessments, after that the input from experts and peers is used to revise the product. There are 3 experts involved in assessing the product, namely learning media experts, curriculum experts, and experts in learning locomotor motion or physical activity and sports.

In the third stage, products are developed according to assessments from experts and peers, followed by formative evaluations. In the fourth stage, products that have been validated by experts and tested in small groups at school are implemented. The first phase of the trial involved 30 students in elementary schools. The purpose of the first trial was to obtain input by identifying and refining the product developed after being reviewed by several experts. Then the product was revised according to the input from the results of the small group trial.

In the final stage, a summative evaluation is conducted through large group trials. The second trial involved students in grade 5 with a total of 100 students from 15 schools in Ogan Ilir Regency. Students will get a pretest before being given learning the basic locomotor motion material based on a game for six meetings; after the last meeting, they received a posttest. Students fill out a questionnaire after learning activities are completed or before the posttest to make responses to the implementation of the game-based locomotor basic motion model. Peers and experts also remain involved to provide final assessments. Then the input data is used to improve the final product.

The implementation of small and large group trials was given in learning process for 10 meetings using 20 types of traditional games for learning locomotor motion. In each meeting, 2 types of traditional games are taught for 2 hours of lessons or 100 minutes. The results of trials and expert assessments resulted that from 20 types of traditional games produced 14 types of traditional games used in learning locomotor motion in schools. Each locomotor motion material is taught using 1 or 2 types of traditional games. Various traditional games that have been produced have been applied in schools for various variations of locomotor movements such as walking, running and jumping

\subsection{Data Analysis}

Needs analysis data validity used judgment expert. The result of needs analysis presented using frequency, average, and percentage. To get an effective and valid product, it is analyzed using 2 methods, namely judgment expert and peer assessment conducted from the beginning of the study to the end. Meanwhile, the results of the students' locomotor ability tests were analyzed using the independent sample T-test.

\section{Result}

The result of model design in the final process showed that there are 16 varieties of basic locomotor motion skills using games for students in elementary school. The descriptive statistic of needs analysis is as follows.

Table 1. The result of students' needs analysis of basic locomotor motion skills

\begin{tabular}{|c|c|c|c|c|}
\hline & Aspect & f & Average & $\%$ \\
\hline \multirow{4}{*}{1} & $\begin{array}{c}\text { Variation of knowledge } \\
\text { in motor skills }\end{array}$ & & & \\
\hline & - $\quad$ Walking & 35 & 0.35 & $35 \%$ \\
\hline & - $\quad$ Running & 58 & 0.58 & $58 \%$ \\
\hline & - $\quad$ Jumping & 7 & 0.07 & $7 \%$ \\
\hline \multirow{3}{*}{2} & $\begin{array}{c}\text { Media of learning for } \\
\text { motor skill }\end{array}$ & & & \\
\hline & - $\quad$ Audiovisual & 50 & 0.5 & $50 \%$ \\
\hline & $\begin{array}{l}\text { - Conventional } \\
\text { media }\end{array}$ & 50 & 0.5 & $50 \%$ \\
\hline \multirow{3}{*}{3} & $\begin{array}{c}\text { Concept of games for } \\
\text { children }\end{array}$ & & & \\
\hline & $\begin{array}{l}\text { Traditional games } \\
\text { model }\end{array}$ & $95 \%$ & 0.95 & $95 \%$ \\
\hline & Modern games & $5 \%$ & 0.05 & $5 \%$ \\
\hline
\end{tabular}

Table 1 concludes that the basic locomotor motion variations consist of 3 types of motor motion. The walking motion got a percentage of $35 \%$, running motion got a percentage of $58 \%$, and the jumping motion got a percentage of $7 \%$. It means that the games used in locomotor learning needed by students are dominated by running motion, while the media used in learning locomotor basic motion is a combination of conventional media in the school environment and audiovisual so that locomotor learning activities become more enjoyable. The locomotor learning concept uses traditional game because students like traditional game activities which are considered easier to do and are often done in everyday life. 
Table 2. The result of teachers' needs analysis of basic locomotor motion skills

\begin{tabular}{|c|c|c|c|c|}
\hline & Aspect & f & Average & $\%$ \\
\hline 1 & 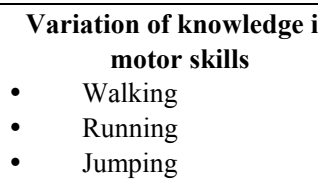 & $\begin{array}{c}13 \\
20 \\
2\end{array}$ & $\begin{array}{l}0.37 \\
0.57 \\
0.06\end{array}$ & $\begin{array}{c}37 \% \\
57 \% \\
6 \%\end{array}$ \\
\hline 2 & 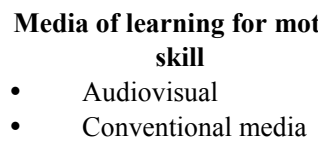 & $\begin{array}{l}17 \\
18\end{array}$ & $\begin{array}{l}0.48 \\
0.52\end{array}$ & $\begin{array}{l}48 \% \\
52 \%\end{array}$ \\
\hline 3 & $\begin{array}{l}\begin{array}{c}\text { Concept of games for } \\
\text { children }\end{array} \\
\text { - } \quad \begin{array}{l}\text { Traditional games } \\
\text { model }\end{array} \\
\text { - } \quad \text { Modern games } \\
\end{array}$ & 30 & $\begin{array}{l}0.98 \\
0.02 \\
\end{array}$ & $\begin{array}{r}98 \% \\
2 \% \\
\end{array}$ \\
\hline
\end{tabular}

The table is teacher perceptions of the locomotor motion needs for students in elementary school. The results obtained have in common with students' perceptions. Analysis of the needs data was also strengthened by the results of interviews with students and teachers who concluded that the games used as a combination of learning locomotor motion were traditional games. It is also aimed at preserving various kinds of traditional games which are fading and eroding with advances in technology. Meanwhile, the media used still combines audiovisuals with simple equipment that is easily available at school or home.

The following Table 3 is the design of basic locomotor motion design using games for students. There are 14 types of locomotor learning.

Table 3 showed the variation of locomotor motion using games. It used the name of traditional games name. Each locomotor training model has different goals and objectives for motion. Meanwhile, the result of the locomotor motion test is that the basic locomotor motion model was feasible because the results of the large group test showed an increase in locomotor ability. The results of the independent sample t-test are presented below Table 4 .

The average of pre-test was 14.67. After the students received treatment with the locomotor basic motion training model, the figure turns out to be 22.22 , which means that the average score of the game-based locomotor basic motion model increased.

The coefficient of the training model before and after being given a play-based locomotor basic motion model is 0.706 with a p-value of $0.00<0.05$, so it can be concluded that the locomotor training model is significant.

Table 3. The final concept of locomotor material

\begin{tabular}{|c|c|c|c|}
\hline & $\begin{array}{l}\text { Name of Locomotor } \\
\text { Motion }\end{array}$ & Goals of Locomotor Motion & $\begin{array}{l}\text { Objectives of Locomotor } \\
\text { Motion }\end{array}$ \\
\hline 1 & Jalan Sepur & Students can understand and perform footstep movements & Walking and running \\
\hline 2 & Menuju Pulau & $\begin{array}{l}\text { Students can understand and make road movements in the } \\
\text { specified direction }\end{array}$ & Walking \\
\hline 3 & Kaki Kika & $\begin{array}{l}\text { Students can understand and perform foot and hand movements } \\
\text { in harmony }\end{array}$ & Slow running \\
\hline 4 & Cari Bulan & $\begin{array}{l}\text { Students can understand and take the path to the specified } \\
\text { direction }\end{array}$ & Walking \\
\hline 5 & Ranjau Darat & $\begin{array}{l}\text { Students can understand and do sloping movements to avoid } \\
\text { obstacles }\end{array}$ & $\begin{array}{l}\text { Walking } \\
\text { Jumping }\end{array}$ \\
\hline 6 & Jalan Layangan & $\begin{array}{l}\text { Students can understand and perform walking movements with } \\
\text { fast foot movements }\end{array}$ & \\
\hline 7 & Jalan Terowongan & Students can make walking movements with variations & Walking \\
\hline 8 & Jalan Tentara & Students can harmonize hand and foot movements & Walking \\
\hline 9 & Lari Semut & Students can do basic running movements & Running \\
\hline 10 & Magnet Bumi & Students can do basic running movements & Running uses the cone media \\
\hline 11 & Tangkap Rusa & Students can do basic running movements & $\begin{array}{l}\text { Running uses the hand } \\
\text { movement }\end{array}$ \\
\hline 12 & Ban Kereta & Students can perform basic motion running in place & Running uses the cone and tire \\
\hline 13 & Jali 212 & Students can understand and perform basic running movements & Running \\
\hline 14 & Lari Base & Students can understand and perform basic running movements & Running \\
\hline
\end{tabular}

Table 4. Average Score of Pre-test and Post-test

\begin{tabular}{ccccc}
\hline & Mean & N & Std. deviation & Std. Error Mean \\
\hline Pre-test & 14.7 & 60 & 4.136 &, 534 \\
Post-test & 22.2 & 60 & 2.998 & .387 \\
\hline
\end{tabular}

Table 5. Paired Samples Correlations

\begin{tabular}{cccc}
\hline & $\mathrm{N}$ & Correlation & Sig. \\
\hline Pre-test \& Post-test & 60 &, 706 &, 000 \\
\hline
\end{tabular}


Table 6. Paired Samples Test

\begin{tabular}{|c|c|c|c|c|c|c|c|c|}
\hline & \multicolumn{5}{|c|}{ Paired Differences } & \multirow[t]{3}{*}{$\mathrm{f}$} & \multirow[t]{3}{*}{$\mathrm{df}$} & \multirow[t]{3}{*}{ Sig. (2-tailed) } \\
\hline & \multirow{2}{*}{ Mean } & \multirow{2}{*}{ Std. deviation } & \multirow{2}{*}{$\begin{array}{l}\text { Std. error } \\
\text { Mean }\end{array}$} & \multicolumn{2}{|c|}{$\begin{array}{l}95 \% \text { Confidence Interval of the } \\
\text { Difference }\end{array}$} & & & \\
\hline & & & & Lower & Upper & & & \\
\hline Pretest-Posttest & $-7,550$ & 2,931 & ,378 & $-8,307$ & $-6,793$ & $-19,953$ & 59 &, 000 \\
\hline
\end{tabular}

Table 6 concluded that $\mathrm{t}$-count $=-19,953$, df $=59$ and p-value $=0.00<0.05$, it means that there is a significant difference in the locomotor ability of elementary school students before and after being treated with a game-based locomotor basic motion training model.

\section{Discussion}

The product trial showed that the movements have been designed to meet the needs of elementary school students for locomotor training. The results of trials in small and large groups showed tested feasibility. The pre-test and post-test were concluded that the students experienced an increase in the ability of locomotor movements in Physical Education and Sports learning. Moreover, the traditional game models that have been developed are also quite varied and have many options for learning locomotor motion of walking, running, and jumping.

Movement combined with a variety of traditional games provides a fun and age-appropriate learning atmosphere for elementary school children. Moreover, traditional games also provide opportunities for students to learn to socialize [25]. Children play traditional games because they require physical activity and social interaction that can meet their energy needs for movement [26]. Besides, the development of a locomotor training model using games is also motor creativity. Each designed traditional game for locomotor motion consists of the concept of motor diversity and interactive communication structures. Each of these movements affects physical, emotional and cognitive development [27].

However, every child has different motor skills. Boys usually have superior motor skills than girls; and their motor development is stable by 7 years old [28]. It means that this traditional games in locomotor motion presented elementary students needs in physical activity. Another case has the same assumption that boys and girls can have different result of physical activity (Carson Sackett \& Edwards, 2019; Burns, Fu, Hannon, \& Brusseau, 2017). In sport activity, the locomotor skills influenced the motoric growth[30]. The motion learning structure is an open pedagogical system that reflects the most common patterns by revealing unique relationships among the elements of the learning stages. Each initial stage of learning in motor action provides a logical basis for the next stage, and the intermediate results are planned according to a certain functional formation, which gradually turns into another, thereby causing a transition to a higher level[31].

This research shows the novelty of the design of each movement in the game that provides opportunities for both male and female students to have the same locomotor skills. Each movement has been shaped with the abilities of each student. The application of different motor skills to children affects motor test results. Therefore, mastery of basic movement techniques can provide different developments for children to master locomotor skills or other physical activities [32]. Study of motoric sports can be used to assess a child's physical skills as an indicator of determining child's healthy development, such as research for the sport of long jump in children aged between 10 and 12 in Germany and Switzerland. Swiss children's skills develop towards German target values [33]. Also, physical, motoric and intellectual activities are interrelated in influencing children's development [34]. The students get interest experience in physical activities [35].

This product has several advantages and disadvantages. Some of the advantages of this product include; a) As a reference for the locomotor playing model. b) The number of variations of the locomotor model that can be selected/applied according to the needs and characteristics of students. c) The combination of various kinds of movements. d) Movement starts from an easy level to a difficult level. e) Movements combining skill training and physical training include eye-leg coordination, balance, accuracy, strength, speed, explosive power, agility and endurance. f) Students feel enthusiastic about doing the exercises. g) The game-based locomotor basic motion model developed is effective and efficient in terms of time and cost. i) it helped teachers in improving students' mastery of basic locomotor movements. j) it contributes to science, especially basic motion science.

Some of the weaknesses of the products are as follows: a) Field trials of this research would be even better if carried out in a wider scope. b) The products still need to develop using another aspect. c) The facilities and infrastructure of training are still limited. d) Photos/pictures of models in the product still need to be improved so that they are more interesting.

\section{Conclusion}

The locomotor motion that has been produced from the development research consists of three types of locomotor motion, namely walking, running and jumping with 14 
types of traditional games. Various kinds of games are used to teach locomotor motion for students in 5 grade elementary school, so that locomotor motion learning activities become more fun. During the locomotor motion product testing activity, students showed enthusiasm and motivation for learning.

Every movement that is exemplified in learning is easy to understand especially when traditional game activities are also games that are often played in students' daily lives. Meanwhile, the results of expert assessment also show that locomotor motion implemented through various types of games for elementary school children is very appropriate because basically children prefer to learn while playing. The results of this study have implications for the development and enrichment of physical education and sports materials, especially locomotor material for elementary school-age children. In addition, the traditional game model in learning locomotor motion is also one way to preserve local culture in the midst of technological advances or modern games.

\section{Acknowledgements}

I am very grateful to all people who help me to finish my research, especially to all students in elementary school Ogan Ilir South Simatera, experts, and my partner in the school.

\section{REFERENCES}

[1] S. Carson Sackett and E. S. Edwards, "Relationships among motor skill, perceived self-competence, fitness, and physical activity in young adults," Hum. Mov. Sci., vol. 66, pp. 209219, Aug. 2019.

[2] L. M. Barnett, E. van Beurden, P. J. Morgan, L. O. Brooks, and J. R. Beard, "Childhood Motor Skill Proficiency as a Predictor of Adolescent Physical Activity," J. Adolesc. Heal., vol. 44, no. 3, pp. 252-259, Mar. 2009.

[3] C. Herrmann, C. Heim, and H. Seelig, "Construct and correlates of basic motor competencies in primary school-aged children," J. Sport Heal. Sci., vol. 8, no. 1, pp. 63-70, Jan. 2019.

[4] K. Sacco, F. Cauda, L. Cerliani, D. Mate, S. Duca, and G. C. Geminiani, "Motor imagery of walking following training in locomotor attention. The effect of 'the tango lesson,", Neuroimage, vol. 32, no. 3, pp. 1441-1449, Sep. 2006.

[5] É. R. Gouveia et al., "Physical fitness predicts subsequent improvement in academic achievement: Differential patterns depending on pupils' age," Sustain., vol. 12, no. 21, pp. 1-9, Nov. 2020 .

[6] H. G. Williams et al., "Motor skill performance and physical activity in preschool children," Obesity, vol. 16, no. 6, pp. 1421-1426, Jun. 2008.
[7] T. Jaakkola et al., "Longitudinal associations of fundamental movement skills with objectively measured physical activity and sedentariness during school transition from primary to lower secondary school," J. Sci. Med. Sport, vol. 22, no. 1, pp. 85-90, Jan. 2019.

[8] A. G. M. de Bruijn et al., "Importance of aerobic fitness and fundamental motor skills for academic achievement," Psychol. Sport Exerc., vol. 43, pp. 200-209, Jul. 2019.

[9] D. Grissmer, K. J. Grimm, S. M. Aiyer, W. M. Murrah, and J. S. Steele, "Fine motor skills and early comprehension of the world: Two new school readiness indicators," Dev. Psychol., vol. 46, no. 5, pp. 1008-1017, Sep. 2010.

[10] S. W. Logan, E. Kipling Webster, N. Getchell, K. A. Pfeiffer, and L. E. Robinson, "Relationship Between Fundamental Motor Skill Competence and Physical Activity During Childhood and Adolescence: A Systematic Review," Kinesiol. Rev., vol. 4, no. 4, pp. 416-426, Nov. 2015.

[11] K. E. Cohen, P. J. Morgan, R. C. Plotnikoff, R. Callister, and D. R. Lubans, "Fundamental movement skills and physical activity among children living in low-income communities: A cross-sectional study," Int. J. Behav. Nutr. Phys. Act., vol. 11, no. 1, Apr. 2014.

[12] A. Han, A. Fu, S. Cobley, and R. H. Sanders, "Effectiveness of exercise intervention on improving fundamental movement skills and motor coordination in overweight/obese children and adolescents: A systematic review," Journal of Science and Medicine in Sport, vol. 21, no. 1. Elsevier Ltd, pp. 89-102, 01-Jan-2018.

[13]E. K. Webster, C. K. Martin, and A. E. Staiano, "Fundamental motor skills, screen-time, and physical activity in preschoolers," J. Sport Heal. Sci., vol. 8, no. 2, pp. 114-121, Mar. 2019.

[14] A. Fisher et al., "Fundamental movement skills and habitual physical activity in young children," Med. Sci. Sports Exerc., vol. 37, no. 4, pp. 684-688, Apr. 2005.

[15] L. L. Hardy, L. King, L. Farrell, R. Macniven, and S. Howlett, "Fundamental movement skills among Australian preschool children," J. Sci. Med. Sport, vol. 13, no. 5, pp. 503-508, Sep. 2010.

[16]E. S. Bryant, M. J. Duncan, and S. L. Birch, "Fundamental movement skills and weight status in British primary school children," Eur. J. Sport Sci., vol. 14, no. 7, pp. 730-736, Oct. 2014.

[17] A. Shams, L. L. Hardy, R. Vameghi, E. M. Loovis, and P. Shamsipour Dehkordi, "Prevalence of fundamental movement skill proficiency among Iranian children aged 2.5-14 years," J. Sci. Med. Sport, vol. 24, no. 1, pp. 74-79, Jan. 2021.

[18] A. Gandotra, E. Kotyuk, A. Szekely, K. Kasos, L. Csirmaz, and R. Cserjesi, "Fundamental movement skills in children with autism spectrum disorder: A systematic review," Research in Autism Spectrum Disorders, vol. 78. Elsevier Ltd, p. 101632, 01-Oct-2020.

[19] A. H, A. B, S. M, K. H, H. S, and Z. V, "The Effect of Traditional Games in Fundamental Motor Skill Development in 7-9 Year Old Boys," Iran. J. Pediatr., vol. 19, no. 2, pp. 123-129, 2009. 
[20] I. H. N and P. H, "Perkembangan Anak Melalui Permainan Tradisional.” Aswaja Pressindo, 2017.

[21] H. Hernawan, Y. Sukarya, and S. Solahuddin, "Locomotor basic motion learning model based on traditional game for basic school students," in Journal of Physics: Conference Series, 2019, vol. 1318, no. 1, p. 012047.

[22] P. D. Loprinzi, R. E. Davis, and Y. C. Fu, "Early motor skill competence as a mediator of child and adult physical activity," Preventive Medicine Reports, vol. 2. Elsevier Inc., pp. 833838, 01-Oct-2015.

[23] M. D. Gall, J. P. Gall, and W. R. Borg, Educational research an Introduction seventh Edition. New Jersey: WIley, 2010.

[24] R. M. Branch, Instructional Design: The ADDIE Approach. New York: Springer, 2009.

[25] Y. Awalludin Nugraha, E. Handoyo, and S. Sulistyorini, "Traditional Game on The Social Skill of Students in The Social Science Learning of Elementary School Article Info," J. Prim. Educ. JPE, vol. 7, no. 2, pp. 220-227, Jun. 2018.

[26] I. Soute, P. Markopoulos, and R. Magielse, "Head Up Games: combining the best of both worlds by merging traditional and digital play," Pers. Ubiquitous Comput., vol. 14, no. 5, pp. 435-444, Jul. 2010.

[27] A. Oboeuf, S. Hanneton, J. Buffet, C. Fantoni, and L. Labiadh, "Influence of Traditional Sporting Games on the Development of Creative Skills in Team Sports. The Case of Football," Front. Psychol., vol. 11, Dec. 2020.

[28] N. C. Valentini, S. W. Logan, B. C. Spessato, M. S. de Souza, K. G. Pereira, and M. E. Rudisill, "Fundamental Motor Skills Across Childhood: Age, Sex, and Competence Outcomes of
Brazilian Children," J. Mot. Learn. Dev., vol. 4, no. 1, pp. 16-36, Sep. 2016.

[29] R. D. Burns, Y. Fu, J. C. Hannon, and T. A. Brusseau, "School physical activity programming and gross motor skills in children," Am. J. Health Behav., vol. 41, no. 5, pp. 591-598, Sep. 2017.

[30] N. A. A. Roslan and B. Abdullah, "Differences in the level of children gross motor skills development in silat, taekwondo and karate in malaysia," Int. J. Hum. Mov. Sport. Sci., vol. 8, no. 2, pp. 57-62, 2020. DOI: 10.13189/saj.2020.080202.

[31] N. V. Ivanovych, "Characterization of the four-stage structure of the process of learning motor actions in sports games," Int. J. Hum. Mov. Sport. Sci., vol. 7, no. 4, pp. 81-88, Dec. 2019. DOI: 10.13189/saj.2019.070403.

[32] C. Bastik, A. Kalkavan, F. Yamaner, S. Sahin, and A. Gullu, "Investigation of Basic Motor Skills According to TGMD-2 Test on Male Athletes of 10 Ages Group Who Participated to Competitions in Different Sports Branches," Procedia - Soc. Behav. Sci., vol. 46, pp. 4741-4745, Jan. 2012.

[33] R. Wittelsberger et al., "A comparative study on sport motoric investigation of children in Germany and Switzerland in height, weight and standing long jump," Sci. Sports, vol. 29, pp. S24-S25, Oct. 2014.

[34] V. Đorđić, T. Tubić, and D. Jakšić, "The Relationship between Physical, Motor, and Intellectual Development of Preschool Children," Procedia - Soc. Behav. Sci., vol. 233, pp. 3-7, Oct. 2016.

[35] M. S. Sumantri, "Learning Model of Fundamental Long Jump Movement Based On Game Approach," Indones. J. Early Child. Educ. Stud., vol. 4, no. 1, pp. 35-41, Jun. 2015. 